\title{
Migrant teenagers in conflict with the law: towards a conceptual transition
}

\begin{abstract}
The following paper develops the concept of "Migrant teenager in conflict with the law" from three dimensions: Social, Biological and legal within the MexicanAmerican border context. At the same time it analyzes a conceptual transition: from transit migrant teenagers to circuit migrant teenagers. This is analyzed to serve as an example of how the actors get a higher degree of vulnerability that makes them take decisions that endanger their physical integrity and their liberty. One of the main points in this paper is that teenagers are easily susceptible of being "recruited" by criminals to commit antisocial activities that could led them to jail. This forced recruitment happens due to the fact that migrant teenagers have accumulated several conditions of vulnerability especially during the conceptual transition they suffer in international frontier. Three research threads are established: legislation concerning migrant teenagers; broken migratory process and the transition from transit migrant teenagers to circuit migrant teenagers in through three dimensions; legal, social and biological This is an effort to bring light to one of the most vulnerable actors in the migrant process: migrant teenagers. This paper takes as an empiric reference the Mexicali Treatment Center for Teenagers, in Baja California Mexico because this actors have several vulnerabilities accumulated and are involved in crimes and are being held incarcerated. The results of this research show that integral attention is limited by the homologation of all the migrants regardless of age, and other characteristics of the actors. This paper suggests make visible the different situations of vulnerability to create integral attention strategies for migrant teenagers.
\end{abstract}

Keywords: Teenagers, migration, deprivation of liberty, teen transit, teen circuit, border
Volume 3 Issue 3 - 2019

\author{
Óscar Bernardo Rivera García \\ Department of Social Research,Autonomous University of Baja \\ California, Mexico
}

Correspondence: Óscar Bernardo Rivera García, Department of Social Research, Autonomous University of Baja California, Mexico,Tel 662325609I,Email oriver90@uabc.edu.mx

Received: May 24, 2019 | Published: June 21, 2019

\section{Introduction}

The concept of migrant teenager in conflict with the law is based on the definition made in the Convention for the Rights of the Child. Article 1 defines a child as a person below the age of 18 , unless the laws of a particular country set the legal age for adulthood younger. ${ }^{1}$ However, it is vital to separate the elements that make up this definition to build the concept. UNICEF considers every person under the age of 18 as a child; this paper will focus on people that are on their late teens. "This category is based upon the definition that the World Health Organization (WHO) has established for teenage hood as the stage between 10 and 19 years old, divided in two main phases: early teenagers (10 to 14 years) and late teenagers (15 to 19 years)". ${ }^{2}$ The first step in this paper is to analyze migrant traits of teenagers, making particular emphasis on the elements that determine a possible migrant condition (biological and social dimensions). The second step is to examine the actor's conceptual transition from transit migrant to circuit migrant (social dimension). The third step analyzes the characteristics of the minor that are in conflict with the law (legal dimension) to determine the exact moment when they enter in conflict with the law, and why.

\section{This paper considers vulnerability as}

An ever present situation characterized by the convergence of circumstances that arises the people's probabilities to suffer contingencies that dramatically reduce their wellbeing. It is a multidimensional concept that tries to identify factors that increase the reproduction of process that endanger the lifestyle and wellbeing of homes and individuals. Even though, all UCC (Unaccompanied
Children) that go through Mexico have all the guaranties related to higher interest of childhood; especial attention is deserved if the actor is involved with migration. The actors, in this case, are migrant children and teenagers. It is the human group that has the greatest amount of vulnerability situations and through this paper it will be analyzed in three dimensions: biological, social and legal-institutional. This paper has as a general objective to show the individual context of those UCC that are stuck in frontier land because they are in a very specific situation of vulnerability. This last part endangers them and puts them in risk of being involved in situations that jeopardize their physical integrity and their liberty. A great part of the objective is focused on the eclectic nature of the frontier space. The fact that different situations of vulnerability converge in this border areas maximizes the possibilities that a MUCC take decisions that involve them into "jobs" that help them survive. The situations of vulnerability have a massive impact in the integral development of social actors, survival is the ultimate objective. Vulnerability has its roots in the interaction between different inner and external home factors that configure the situation in a space and moment given. The inner factors are the ones the individuals and homes have under their control. There are also action strategies the actors have that allow them face the external factors (social and natural shocks). When there's a rise in diversity and quality of resources available to individuals and homes during an external event the vulnerability levels will decrease. The degree of vulnerability of an individual or home depends on the shocks they face and the resilience they show during those shocks to avoid impoverishment process.

The combination of different factors means a potentialization of vulnerability this is true to every UCC even without the migrant 
variable. The biological dimension is used to set an example of the main objective of this paper. In this dimension the interaction of inner and external factors must be consider in addition to the migrant element when the teenager takes the decision to move from his birth place in search for better conditions to improve his self-development Collective, at this point, it is conceptualized as a minor migrant. When the minor migrant arrives to an unknown border space but has heard through several social networks he has, (friends, family, neighbors etc.). Once at the border, with or without help, the minor migrant will try to cross to his destiny country-at this moment he is conceptualized as a transit minor migrant. If the minor migrant is caught, he has the options of going back to his birth place or stay in the frontier until he achieves his objective of crossing. When the MUCC take the decision to move they are involved in a social dimension where the structural elements do not ensure an integral development.

\section{Methodology}

Defining the subject for this study was a methodological challenge; the methodological strategy included a survey applied to 27 teenagers kept inside the Mexicali Treatment Center for Teenagers, in Baja California, Mexico. The survey was helpful to identify five teenagers with migrant experience, either accompanied or unaccompanied. The next step was interviewing those five teenagers in order to identify several situations of vulnerability and how they interiorize those experiences during the growing process and their own self-definition. The attention given to detained teenagers is important because they have gone through several situations of vulnerability and also have committed a felony that led their current status as inmates. The characteristics of those surveyed teenagers are as follows in the next Table 1. The interviewed teenagers fulfilled the profile of the next variables of the survey: birth place outside Baja California Place where they are being held, activity they were engaged before enter the center, previous place where they used to live, migrant experience amount of times crossing to United States. Two additional deep interviews were made to personnel that attend teenagers in the Mexicali judiciary system for teenagers and a former director of a treatment center for teenagers.

There is the consideration that Every UCC that migrates is aware of the situations he may experience. "To think about migrant children implies conceptualize the agency and the structure in terms of a double sense relationship: the actions of the migrant children affect the structure as well as they are affected by the structure itself'. This quote refers to those structures that amplify poverty, violence, lack of education or family life, the direct effects they have over the integral on the UCC. The actions taken by the migrant UCC affect the structural environment, this limit the effects of the attention strategies. This means that there is a reproductions of different cyclic elements that extent the situations of vulnerability. Extortion, kidnaping and illegal passing fees are some of the actual scenarios that transit migrants face; such situations aren't related to the migrant phenomenon itself but they are part of the characteristic of the space where the transit takes place. ${ }^{3}$ The methodological strategy followed is qualitative one because one objective is to interpret inter-subjectivities related to the normalization of the vulnerability en specific actors such as teenagers. Even though I do not pretend this paper to be representative, the data obtained shows there is presence of Migrant Teenagers in Conflict with the Law inside the Mexicali Treatment Center for Teenagers. This information has a lot of meaning because there are many threats to the physical integrity of migrant children and teenagers throughout the border, such as: being held into forced prostitution, abuses, mistreatments and discrimination. ${ }^{4}$ Taking a conceptual approach turns out vital because it helps to create a definition of Migrant Teenagers in Conflict with the Law to identify the vulnerability situations that can lead the actors to take decisions that can put them at risk physically and jeopardize their liberty.

\section{Biological and social characteristics}

The interest to set a particular stage of human life goes hand in hand with the political, economic and cultural changes in addition to industrial and educational development, also to the part that young people play these days. In recent generations, there is an early sexual maturation and active participation in different spheres such as social, political, cultural and economic; these represent a challenge to the countries around the world. ${ }^{2}$ Above all, because it is in this stage of life when they are set as a particular group of society with rights that ensure they can enjoy mental and physical health, access to education, and active participation in society, so they can thrive. The United Nations General Assembly defines 'youth' as persons between 15 and 24 years of age, and 'young people' as those between 10 and 24 years of age. These definitions were adopted during the International Year of the Youth in 1985 and have been generally used by United Nations agencies and other partners. In general, the overlapping use of these definitions is recognized, with 'adolescents' and 'youth' often used interchangeably with 'young people'. ${ }^{5}$ Based on the previous statement, this article understands teenager to be the person between 14 and 19 years old. This decision is taken starting from some biological characteristics included in the definition itself, psychosocial issues such as the quest of self being, independence like identity attitude, group behavior, development on concrete to abstract thinking, intellectual necessity, sexual behavior, the election of a professional activity and the need to be trained on it, and finally, to question and set their life project. ${ }^{2}$ These elements: the evolution on the thinking, the choice of a profession and the other elements are the main elements that are considered when the decision to migrate is taken or not, having in mind that in their home countries they don't have an opportunity to develop those elements. In this sense, the International Organization for Migration (IOM) considers migration as: a population movement, either across an international border, or within a State, encompassing any kind of movement of people, whatever its length, composition and causes; it includes migration of refugees, displaced persons, uprooted people, and economic migrants. ${ }^{6}$

Ruiz $^{7}$ defines migration as people movements that have the intention to change the residence from a place of origin to a final place, going through some geographical limit that is usually a political administrative division. ${ }^{7}$ One of the main reasons why the geographical movement is given is to look for better life conditions in the economic realm, but it is not the only one: it can also be the familiar reunification, scape from violent environments, flee from a context of exploitation, as a social upgrading, among others. The migration process is known based on four main aspects from where the individual that takes the decision to move is exposed to:

a) Factors of the origin area (extreme poverty and violence, are possible reasons).

b) Aspects associated to the arriving area (in this case the advantages can be, more employment and safety). 
c) Obstacles that come (consider the advantages they have, and at the same time the disadvantages to make the trip: information that they can have).

d) Personal reasons: they include several reasons from familiar reunification to persecution related to violence, among others. ${ }^{6,7}$

Thus, a person considered as a migrant has to go through these four aspects.

1. To have a possible reason or motive.

2. Predetermine the spatial movement as the most likely answer to that reason or motive.

3. To have tangible elements to get the answer they look for (enough information to start a possible migration).

4. Consider multiple personal factors such as family reunification or job offers, these are the most common ones.

In reference to the main actors in the migrant process, the IOM makes the following statements regarding the process of defining what a migrant is: At the international level, no universally accepted definition of migrant exists. The term migrant is usually understood to cover all cases where the decision to migrate is taken freely by the individual concerned for reasons of "personal convenience" and without intervention of an external compelling factor. This term therefore applies to persons, and family members, moving to another country or region to better their material or social conditions and improve the prospect for themselves or their family. ${ }^{6}$

I give the following precision to the IOM definition of the term migrant: While the previous definition has recognized spatial mobility as part of the search for "better" life conditions, I would also point out that external factors also influence the decision for people to move. The search for a better life in and of itself means that an external influence (economic, political, cultural and social) is having a meaningful presence in the moment of showing that there are options outside the immediate context, and therefore people make the decision to move based on those external elements. In order to achieve my goal for this paper, I take into account a definition of the term migrant given by the IOM with which I completely agree: Unaccompanied minor Persons under 18 who are not accompanied by a parent, guardian, or other adult who by law or custom is responsible for them. Unaccompanied minor present special challenges for border control officials, because detention and other practices applied to undocumented adult aliens may not be appropriate for minors. ${ }^{6}$ There is a particular interest to highlight the second part of this definition: unaccompanied minors present special challenges for border control officers. This element will be further approached in the section entitled Teenagers in Conflict with the Law in this paper. From what I have exposed so far, it should be considered that a Migrant teenager is any person between 14 and 19 years of age that has experienced a movement from his or her immediate place of residence and went out looking for material elements to get a better life (whichever elements they may be). This definition is identified in two dimensions: biological and social. The biological dimension shows itself into the intrinsic elements that are implied in this particular stage of life, which goes from the 14 to the 19 years old. Moreover, the social dimension presents itself through the contextual-structural-variables that lead the teenagers to move from their place of origin. At this point, it is important to take into account that the Migrant teenager faced factors associated to his home region in order to move from there, and also to pre-visualize elements of the arriving area as the answer to the movement. The teenager is conscious of the obstacles that intervene whenever he moves but he finds himself motivated to take the decision due to his personal factors. In the next section I address the conceptual transition from Transit Migrant to Circuit Migrant, as a basis to establish that this is the moment teenagers may acquire a vulnerability element that will affect their decision making process that may risk their physical integrity and liberty.

\section{Transit migrant teenagers and circuit migrant teenagers}

This document suggests that every Migrant Teenager that has experienced repatriation can develop a conceptual transition. This transition is one of the moments that have a higher vulnerability for Migrant Teenagers. I retake several conceptual proposals to analyze this transition. A groundbreaking research from 1990 shows this diversity in the minor migrants during the migration process through the Mexican-American border and offers the first characterization of the minors that were taken care of in the Scalabrini Center in Tijuana.

1. Minors that move through the border to reunite with their families.

2. 12-13 years old minors from a lower-class family.

3. Minors that left their families in search for adventure and also dropped out of school, or a minor that has family problems.

4. Theminor that is deported to Mexico, after being caught in the US for breaking the law. ${ }^{4}$

The Ramirez ${ }^{4}$ research is truly exceptional, since it makes a conceptualization of the migrant actors, specially teenagers. The Authors recognize the migrant actor's extreme social vulnerability and legal defenseless condition about their rights. They explain that at the early stages of research, they worked with the concept of Border Minors to refer to all migrant boys, girls and teenagers (MBGT). They were defined as every minor repatriated, rejected and returned to Mexico from the United States, as well as every migrant minor. The concept is unfitted to grasp the reality that MBGT experience.

A first analysis is in the definitions of "Transit Migrant" and "Circuit Migrant." In order to do so, I take into account the results presented by Mendez: ${ }^{4}$

a) Transit Migrants: are defined as such by their strong family ties and because they have a home in the United States.

b) Nomad Migrants: they are the ones that do not have family or friends living in United States or they did not comment on it.

c) Trans-frontier Migrants: They live in Mexican border towns and do not have a defined familiar core, and have lived in the streets. ${ }^{4}$

No matter the case, they live a moment of complete solitude, without help and without any necessary tool to claim for their rights that are established in different local and international legislations. They are alone and with a frustrated migrant journey. They are without any care or protection from their parents or their legal tutor; consequently, they suffer this separation in both the social and psychological levels. ${ }^{9}$ The former Director of the Treatment Center for Teenagers states that: "The teenager is susceptible to be used by adults to commit felonies" (Personal Communication, May 11th 2017). It reinforces the idea that when a teenager has been repatriated to a border, such as the one in northern Mexico, he finds himself in the moment of the 
highest uncertainty. He identifies a situation of vulnerability regarding the social dimension that holds migrant teenagers. The uncertainty of getting to their destinies is exponentially multiplied if they are caught crossing the border, and then repatriated, because their legal and personal status are never explained to them during the repatriation process. In each repatriation case, a teenage invisibility takes place, since they are kept blank about their legal situation..$^{10}$ The moment of highest uncertainty is when they are repatriated and stuck in a border space. They are caught within the social sphere that encompasses the migrant characteristics of the teenagers. It is in this point of the migrant process where teenagers are exposed to several social, political and cultural elements that can put their physical integrity at risk, and can be pushed to take decisions that can jeopardize their final goal and lose their freedom. A migrant teenager, whether male or female, that is looking to get across this border space towards his or her destiny can be tagged as a circuit migrant BGT. The past lines are relevant if we take into account all the possibilities that come with the implication of being tagged as a circuit migrant teenager.

\section{Circuit Boy, girl, and teenager are defined as:}

all those minors that recurrently go across the US-Mexico border in an undocumented way motivated by reasons that are not related to job searching or family reunification. They can be classified in two groups: the first kind of BGT that are not from Mexican border cities. They cross the border as a life experience or rite of passage and they obtain a reward in the symbolic plane: they get experience, they show maturity and/or bravery. The second kind includes minors (boys, girls, and teenagers) that are involved in human trafficking networks, as guides during the border crossing, or with organized crime bands as smugglers. ${ }^{10}$ I add this conceptualization to the three previous ones given by Mendez, and by applying them as a base, I can define what I mean by Circuit Migrant Teenager and Transit Migrant Teenager.

1. Circuit Migrant Teenager (CMT) is the teenager that by any circumstances lives permanently or stationary in any border space. They can be accompanied or by themselves. They are actors that are conditioned by their precarious state; they are pushed to outlaw job options: they work loading and carrying merchandise (normally drugs); they are hired as guides by polleros or coyotes (people who smuggle undocumented people across the border) and other illicit jobs.

2. A Transit Migrant Teenager (TMT), is the one that uses the border spaces solely to try to get to the United States, their objective is migrant functionality. The border space is used only as a mean to get to their destiny. If they don't meet their goal (to cross into the United States) and are repatriated, they usually go back to their place of origin.

Both definitions have the base elements proposed by Ramirez, ${ }^{4}$ Mendez ${ }^{8}$ and Moreno and Avedaño. ${ }^{9}$ It is necessary to make a clarification, both concepts (CMT and TMT) do not ignore individuality. In other words, the same actor can be a TMT as well as CMT. A TMT that arrives to a border space can experience a conceptual "transition" to a CMT due to the vulnerability characteristics exposed before and are showed next Figure 1.

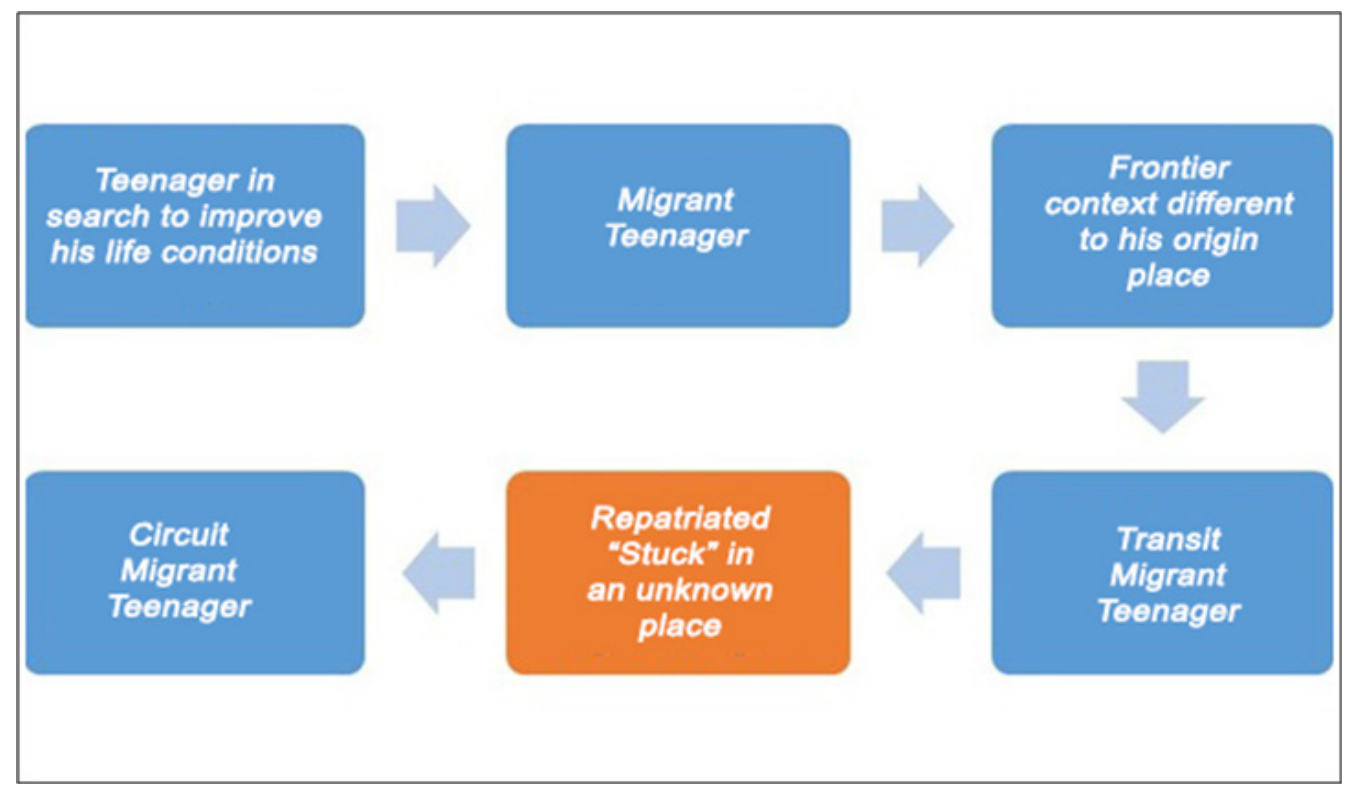

Source: Own elaboration.

Figure I Conceptual Transition for Migrant Teenagers.

\section{Teenagers in conflict with the law}

Up to this point, I have defined Transit Migrant Teenager and Circuit Migrant Teenager. Elements that are contained into two different spheres: social and biological. In this part of the paper, will define the exact moment when the teenager is in Conflict with the Law and why. Take again the definition of the IOM for unaccompanied minors, particularly the part about detention rules: Unaccompanied minors present special challenges for border control officials, because detention and other practices used with undocumented adult aliens may not be appropriate for minors. ${ }^{6}$

To determine when a teenager is in conflict with the Law I take upon the notion of delinquent behavior, it is mandatory for all the considered States that the [teenager] imprisonment must always be the last resort, only after every other educational option available in 
the community has been attempted. ${ }^{11}$ This quote takes importance if we consider that one of the goals of this paper is to present the probability that a migrant teenager, either alone or accompanied, may be pushed to take a harmful decision when he is stuck in a border space after being repatriated. Start from the assumption that the Mexican Judiciary System applied to Teenagers sets as an objective to consider the incarceration as a last resort option and for the shortest period of time possible-this is also contemplated in several international regulations. The former Treatment Center for Teenagers Director defines Teenagers in Conflict with the Law as follows: Every minor between the age of 14 and 18 years old that has committed a felony. The teenagers arrive to the Treatment Center, only, as the law says, after committing serious offenses. Only teenagers that have committed serious offenses will be imprisoned. For example, murder, all crimes are serious in the Baja California State Penal Code $[\ldots]$ robbery, homicide, kidnapping and rape. In the teenagers' study, most of them are imprisoned for murder (Baja California), for murder and organized crime. (Personal Communication, May 11th 2017). A vital tool to build the concept is the "United Nations Standard Minimum Rules for the Administration of Juvenile Justice ('the Beijing Rules')." In the second section of the "General Principles" entitled "Scope of the Rules and definitions used" in the 2.2 says:

a) A juvenile is a child or young person who, under the respective legal systems, may be dealt with for an offence in a manner which is different from an adult;

b) An offence is any behavior (act or omission) that is punishable by law under the respective legal systems; and

c) A juvenile offender is a child or young person who is alleged to have committed or who has been found to commit an offence. ${ }^{12}$

This same document establishes the age of criminal responsibility: 4.1 In those legal systems recognizing the concept of the age of criminal responsibility for juveniles, the beginning of that age shall not be fixed at too low an age level, bearing in mind the facts of emotional, mental and intellectual maturity. ${ }^{12}$ The Mexican regulation is in the National Law of the Integral Teenage Criminal Justice System (NLITJPS) ${ }^{1}$ published in Mexico's Official Journal (FOJ) on 06-16$2016^{13}$ and it states the ages and groups as follows:

i. Teenager: Person whose age is between 12 years old and younger than 18 .

ii. Age group I: Teenager group that due to their age are set inside the 12 and less than 14 year-old range;

iii. Age group II: Teenager group that due to their age are set inside the 14 and less than 16 year-old range;

iv. Age group III: Teenager group that due to their age are set inside the 16 and less than 18 year-old range. ${ }^{13}$

In regard to age in the Mexican system, the NLITJPS states that the age groups that are susceptible to be imprisoned are II and III. The Law establishes that the authorities have the obligation of referring the teenagers in Age Group I to the Child protection institution, in this case the National System for the Integral Development of the Family (NSIDF). The Convention on the Rights of the Child says in its article 37 that: The arrest, detention or imprisonment of a child shall be in conformity with the law and shall be used only as a measure of last

\footnotetext{
${ }^{1}$ To this date is the only Active Document about the regulation on teenagers' participation in antisocial behavior.
}

resort and for the shortest appropriate period of time. ${ }^{1}$ Therefore, the imprisonment or deprivation of liberty of a teenager must be the last resort and it is: "any form of detention or imprisonment or the placement of a person in a public or private custodial setting, from which this person is not permitted to leave at will, by order of any judicial, administrative or other public authority. ${ }^{13}$ The past lines imply that in order to build the concept of Migrant Teenagers in Conflict with the Law we must focus in the classification of the crimes that require imprisonment in Mexico. In Article 1 of the NLITJPS: This Law is public and has to be obeyed in all the Mexican territory. It will be applied to every person that has been attributed with a conduct defined as a crime by the criminal laws and is between 12 and 18 years old. ${ }^{13}$ The NLITJPS is based upon the Unicef Convention on the Rights of the Child. ${ }^{1}$ We will support our concept in the NLITJPS to define the crimes that are punished through privation of liberty, particularly the Title VII, Chapter II, article 164 about confinement; that says: The confinement will be used as an extreme option and for the briefest period possible for teenagers that at the moment of being found guilty of a crime are in the age groups II and III. The jurisdictional body must carefully consider the causes and effects whenever it uses this option, having in mind its imposition as a last resort measure [...].

The present Law states that imprisonment can be applied in any of the following cases, all of them are in federal law or their local equivalent:

a) About the crimes in the General Law on Sanction and Prevention of Kidnaping [...]

b) About the crimes in the General Law on Sanction and Prevention of human trafficking and forced prostitution $[\ldots]$

c) Terrorism, as is understood in the Mexican Federal Criminal Code

d) Engraved Extortion, when it takes place in the conspiracy mode

e) Against the Health, as is in article 194 [...] of the Federal Penal Code

f) Possession, carrying, manufacture, import and stocking of forbidden fire weapons and/or reserved only for the use of Army, Navy and Air Forces

g) Intentional manslaughter in all its variations, including femicide

h) Rape

i) Intentional injuries that can jeopardize life or leave the person in a permanent disability

j) Violent grand theft. ${ }^{13}$

Every time a teenager gets involved or is proven in a fair trial that he has participated or committed any of the previous crimes will be object of imprisonment in a public institution called "Internal Treatment Center for Teenagers." In Mexico, nationwide, a teenager is in conflict with the Law in the moment his or her direct or indirect participation in a crime according to the NLITJPS has been proven. If the teenager is ether in central Mexico or in the northern border of the country, the international, national and local laws will establish the moment and process to define the moment when a Teenager is in Conflict with the Law. So far, I can say that the Teenagers in Conflict with the Law are all those teenagers that are deprived of their liberty and are held in any of the Internal Treatment Centers for Teenagers. According to the former director, a Treatment Center for Teenagers is "A place where teenagers in conflict with the law are confined, in 
practice. In theory, it has to be the place where the teenagers justify themselves in the penal law" (Personal Communication, May 11th 2017). In this sense and based on the NLITJPS a Treatment Center for Teenagers must have at least:

1. Adequate spaces for access and attention for the prisoners that can provide privacy, visual stimuli, and gender based necessities.

2. Adequate alarm system, proper evacuation routes and safe keep.

3. Should not be located in dangerous areas.

4. Proper facilities according to gender, age, and legal status.

5. Adequate areas for family visits, legal representation visits and intimate visits.
All teenagers that have been sentenced or that are in the middle of the process; or that received a recommendation for detention are in a Treatment Center. I want to make clear my commitment to the principle that every teenager that is imprisoned has been through (or currently is in) a fair trial that decided his/her legal situation if his/her participation in one of the crimes of the classification by the NLITJPS is proven. It is not my intention to judge on the fair trail process every teenager has a right to, and maintain that the innocence presumption of any boy, girl or teenager is an essential condition for them. Poverty and marginalization do not automatically create delinquency, since there are other factors that influence the process, such as material, individual and social development; individual aspects of life that lead a person with no other option of income to become susceptible of committing crimes. ${ }^{14}$

Table I General characteristics of inmate teenagers held in Mexicali, Baja California, Mexico (October 2018)

\begin{tabular}{|c|c|c|c|}
\hline Characteristic & Category & Sub Total & Percentage \\
\hline \multirow[t]{2}{*}{ Sex } & Male & 26 & 96 \\
\hline & Female & 1 & 4 \\
\hline \multirow[t]{2}{*}{ Age } & $15-17$ & 19 & 70 \\
\hline & 18-more & 8 & 30 \\
\hline \multirow[t]{2}{*}{ Birth place } & Baja California & 21 & 78 \\
\hline & Different State & 6 & 22 \\
\hline \multirow[t]{2}{*}{ With children } & Yes & 5 & 19 \\
\hline & No & 22 & 81 \\
\hline \multirow[t]{2}{*}{ Civil status } & Single & 25 & 93 \\
\hline & Consensual Union & 2 & 7 \\
\hline \multirow[t]{2}{*}{ Living companion before entering the center } & Familiar & 12 & 44 \\
\hline & Non familiar & 15 & 56 \\
\hline \multirow[t]{2}{*}{ Can read and write } & Yes & 26 & 96 \\
\hline & No & 1 & 4 \\
\hline \multirow[t]{3}{*}{ Main activity before entering the center } & Working & 6 & 22 \\
\hline & Studying & 11 & 41 \\
\hline & llegal activities & 10 & 37 \\
\hline \multirow[t]{2}{*}{ First time inside a place like this } & Yes & 14 & 52 \\
\hline & No & 13 & 48 \\
\hline \multirow{2}{*}{$\begin{array}{l}\text { Number of times successfully crossing to United States(without } \\
\text { documents) }\end{array}$} & Never & 15 & 56 \\
\hline & More $\tan 2$ & 12 & 44 \\
\hline Total & Teenagers & 27 & 100 \\
\hline
\end{tabular}

Dimensionality of the concept: migrant teenager in conflict with the law

A Migrant Teenager in Conflict with the Law is contained into three dimensions. Each one has very distinctive characteristics. Table 1 , shows every definition and characteristics on all three dimensions. It is very important to consider this information since it represents different vulnerability situations that when accumulated put the MBGT to several circumstances that have not been considered when they are offered an integral attention (Table 2). The previous lines are relevant because they make reference to an accumulation of vulnerabilities that can lead to a situation where organized crime and other groups consider migrant teenagers as new viable human resources. The concept of Migrant Teenagers in Conflict with the Law that I am applying refers to every person between 14 and 19 years of age, who is inside a Treatment and Executive Center for Teenagers that has 
experienced a movement from his birthplace or residence in search for elements that allowed him an alternative to improve his life quality. In the next section, I will operationalize the importance of this concept in the border context. What I am aiming to find is a correlation between a geographical place and the antisocial jail worthy behavior committed by migrant teenagers. I will use some data from Mexico's National Institute of Geography, Statistics, and Computing (Inegi) based on the Mexican Government's Public Safety and State Penitentiary System Census from 2016, and also on some data from the Mexicali Attention Center for Teenagers in Baja California, Mexico. I make the assumption that in the moment when a Migrant Teenager experiences a conceptual transition, he may take some decisions that may jeopardize his physical integrity and his liberty, because in the moment when the possible participation of a minor in a crime is proven, it is best to look for the greater good of the child. As an example, I present a quote from what Ana Luisa Guerrero published: Fernando is 16 years of age and has spent two years smuggling migrants between Tamaulipas and Texas. He has been deported three times already by U.S. Customs and Border Protection, better known as the border patrol. However, he

Table 2 Conceptual dimensions of migrant teenagers in conflict with the law says that he's going to continue in that line of work because he gets a great payment, somewhere around 70 U.S. dollars for each person he smuggles, and he manages to cross the Rio Grande three times per week, each time with a group of up to ten persons. He is one of the so called "polleritos" or "coyotitos" (little coyotes), children or teenagers that are recruited by the organized crime bands, and whose major advantage is that because of their legal status as minors, U.S. authorities don't charge them with any felony and the only retribution they get is being deported to Mexico. Authorities call them "Circuit Minors" and they are related to human trafficking and drug smuggling. We have identified that some of these minors do not only traffic humans, but drugs as well. Minors represent the new human resource used considering the following two criteria: that they are underage and that those activities are not punishable neither in the U.S. nor in Mexico, and they are experienced at crossing the border line illicitly, which makes them highly valuable because they constitute a valuable social capital, because of the vast social networks they create, the routes they know and the people they meet. ${ }^{15}$

\begin{tabular}{|c|c|c|}
\hline Dimension & Characteristics & Defination \\
\hline \multirow{3}{*}{ Biological } & I.Younger than 18 years old (Unicef). & $\begin{array}{l}\text { Every person between } 14-19 \text { years old that has } \\
\text { the proper elements to be considered a social and } \\
\text { historical actor with its own cultural, social, symbolic } \\
\text { and economic capital. }\end{array}$ \\
\hline & $\begin{array}{l}\text { 2. Stage of life when there are political, social cultural, and economic } \\
\text { changes; sexual maturity; and active participation in the social, } \\
\text { political, cultural and economic spheres. }\end{array}$ & \\
\hline & $\begin{array}{l}\text { 3. Psycho-social aspects, group behavior tendencies, evolution in } \\
\text { the thinking process from concrete to abstract and the necessity to } \\
\text { learn and prepare for a job. }\end{array}$ & \\
\hline \multirow{5}{*}{ Social } & $\begin{array}{l}\text { 4. People movements that have the intention to change the } \\
\text { residence from a place of origin to a final place, going through some } \\
\text { geographical limitation which is usually a political-administrative } \\
\text { division (iom 2006). }\end{array}$ & $\begin{array}{l}\text { Every person between } 14-19 \text { years old that has } \\
\text { experienced a displacement from his/her place of } \\
\text { living in the previous three months or more, who } \\
\text { moved in the search for elements that allow him/her } \\
\text { to obtain an answer to his/her needs. }\end{array}$ \\
\hline & 5. Should have a reason or motive to move. & \\
\hline & $\begin{array}{l}\text { 6. Has to consider the movement as the proper answer to his } \\
\text { personal situation. }\end{array}$ & \\
\hline & $\begin{array}{l}\text { 6. Has to consider the movement as the proper answer to his } \\
\text { personal situation. }\end{array}$ & \\
\hline & $\begin{array}{l}\text { 8. Personal elements, that combined with the reasons and motives, } \\
\text { stimulate the decision of moving. }\end{array}$ & \\
\hline \multirow{7}{*}{ Legal } & $\begin{array}{l}\text { 9. International normativity: Convention on the Rights of the Child } \\
\text { (Unicef 2006). }\end{array}$ & $\begin{array}{l}\text { People between } 14-19 \text { years old that are deprived } \\
\text { of their liberty and are imprisoned in an Evaluation } \\
\text { and Executive Center for Teenagers. }\end{array}$ \\
\hline & I0.“Beijing Rules” (Unicef I985). & \\
\hline & $\begin{array}{l}\text { I I. United Nations standards and norms in crime prevention and } \\
\text { criminal justice (onudc 2007). }\end{array}$ & \\
\hline & 12. National regulation: & \\
\hline & $\begin{array}{l}\text { I3. National Law of the Integral Teenage Justice Penal System (cdcu } \\
\text { 20|6). }\end{array}$ & \\
\hline & I4.Article I64 Confinement (cdcu 20I6). & \\
\hline & $\begin{array}{l}\text { I5. Imprisonment or deprivation of liberty: “( } \ldots) \text { any form of } \\
\text { detention or imprisonment or the placement of a person in a public } \\
\text { or private custodial setting, from which this person is not permitted } \\
\text { to leave at will, by order of any judicial, administrative or other } \\
\text { public authority (onudc } 2007) \text {. }\end{array}$ & \\
\hline
\end{tabular}

Source: Own elaboration. 


\section{Operationalization of the concept of migrant teenager in conflict with the law}

One of the objectives of this paper is related to the accumulation of situations of vulnerability faced by the MUCC. It is very important to bring to light actors such as MUCC, the levels of vulnerability that they face are schematized in Figure 2. This document considers the situations of vulnerability in three dimensions: Biological Vulnerability, social vulnerability and legal-institutional vulnerability. If a MUCC shows the three dimensions means that he has grown into a way of being and a way of belonging that change his identity. In this case we use what Grace says about the way of being and the way of belonging: Ways of being and ways of belonging are terms that refer to different ways in which identity comes to light from several levels of consciousness on the social actions of the person. Therefore, identity comes from actions with a conscious, explicit and visible meaning but also include actions with a sense is unconscious, implicit and hidden. This is an effort to operationalize the concept; I am taking as a base the data from INEGI's National Government Public Safety and State Penitentiary System Census, 2016. Where the data shows that there were 7,785 teenagers under treatment inside the Treatment Center for Teenagers in Mexico the age range goes from 12 to 18 years old and more Table 3.

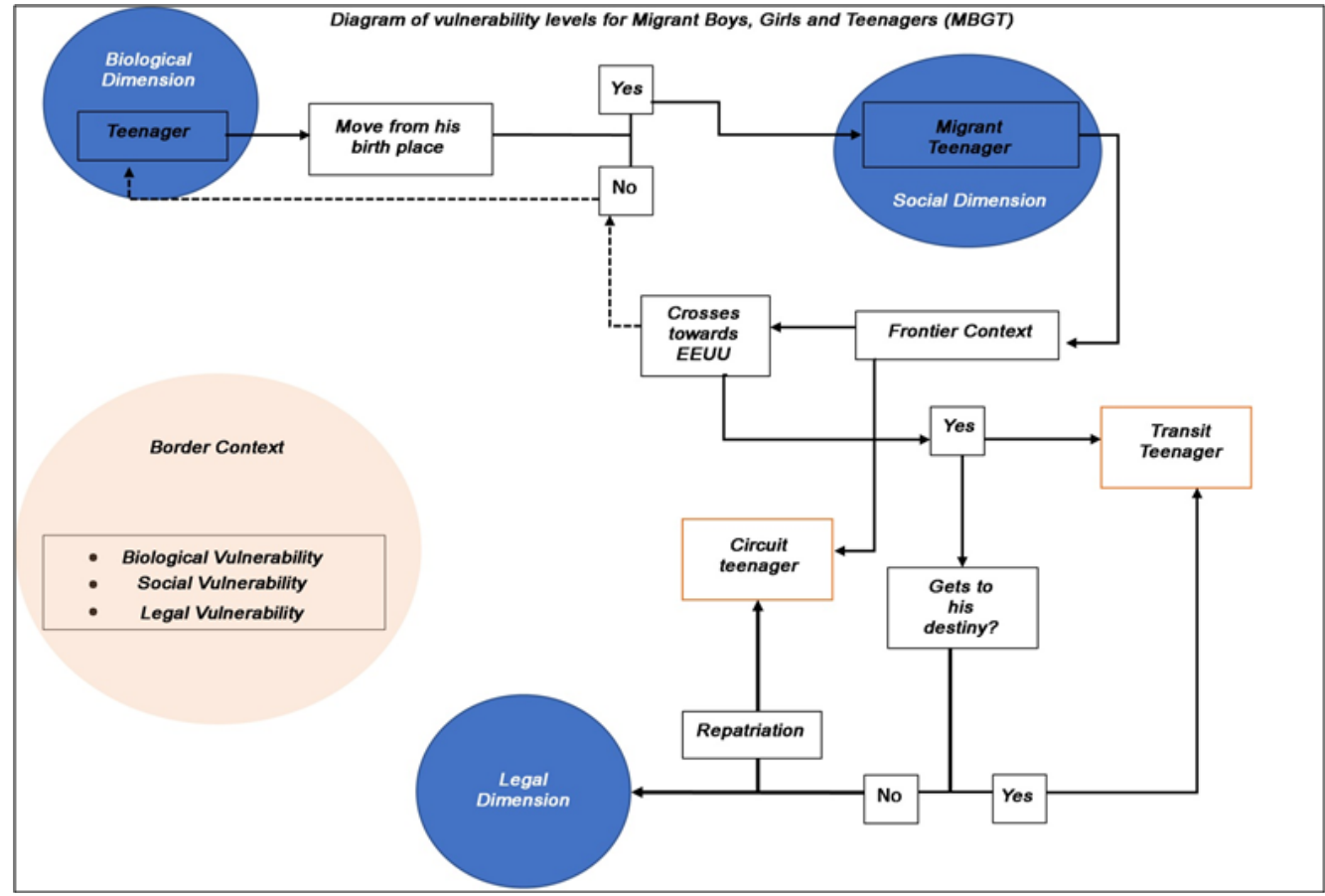

Source: own elaborated.

Figure 2 Levels of vulnerability.

Table 3 Population inside the centers for Teenagers, Admitted (higher number), 2016

\begin{tabular}{ll}
\hline State & Total \\
\hline National Total & 7785 \\
Baja California & 672 \\
Chihuahua & 636 \\
Distrito Federal & 1146 \\
Jalisco & 586 \\
Nuevo León & 959 \\
Sonora & 642 \\
Tamaulipas & 629 \\
\hline
\end{tabular}

Source: own elaboration with Inegi data, 2016.
Table 2 exposes the states that represent the highest number of teenagers admitted into the Treatment Centers. Excluding Mexico City and Jalisco, the rest are the northern Mexican Border States. The nationality of the teenager admitted, Inegi gives the following information Table 4 . The foreign nationality that has the highest numbers in Tamaulipas, Chihuahua and Baja California is the American; also, there is presence of the nationalities that form the northern triangle that goes through Mexico (Guatemala, Honduras and El Salvador). ${ }^{2}$ I operationalize the concept by considering that a migrant boy, girl or teenager is endangered by several vulnerability situations such as, traveling accompanied or alone, being minor and in some cases travel without the necessary documents to enter and to stay in a foreign country. ${ }^{10}$ Being in a Treatment Center for Teenagers in a place that is unknown to them can trigger even further the situation of vulnerability they experience. A decision that lead to a confinement

${ }^{2}$ For more information related to the Northern Triangle, check: Unicef (2015). Migrant returned boys, girls and teenagers. An analysis of the contexts and the responses from the services and protection policies in El Salvador, Guatemala, Honduras and Mexico. Buenos Aires: Unicef, Save the Children. 
because they were at the wrong place at the wrong time: repatriation in a geographical space that is unknown, they are alone and they don't know anyone. I begin my analysis from the assumption that teenagers are the most susceptible of being recruited by criminals because of their condition (being minor). Some Laws try to protect the integrity of the teenagers that committed an antisocial behavior, and when that happens the priority is to reintegrate them to society. Article 26 of the NLITJPS states that the presumption of innocence establishes that: every teenager must be considered and treated as innocent during all stages of the process as long as there is no guilty sentence given to him by a Judiciary Organ in the terms established by this Law. ${ }^{13}$ This is seen as a space of opportunity by the organized crime groups and they have in the teenagers their "new human resources". ${ }^{15}$ Teenagers are disposable traffickers and hit men, an expendable trope whose recruitment brings money and saves many resources for the cartels and their 47 cells in Baja California; but this phenomenon has not sensitized local authorities, as "all groups recruit children" and have their small army of minors. ${ }^{16}$ A teenager can be released almost at any moment during a legal process thanks to the legal dimension he is included in. Ortiz offers an example, present here with some observations about place: He is barely 12 years old but acts as if he is older. When cops found him trading a piece of paper for money, he tried to flee and then threatened them. Cops asked him why he ran, he did not answer. He later told them his name was Alberto and asked them to let him go because the dope was his boss' and he would kill them all if they took it. "The boy said that we couldn't do anything to him because he was a minor, in other words, we couldn't arrest him, we couldn't charge him with anything and he already knew we weren't allowed to interrogate him, he was completely trained and informed about his rights and the restrictions we authorities have in cases with minors involved." This was said by sub-secretary Jose Gil Garcia from Intelligence sources and Information from the Mexico City Bureau of Public Safety. ${ }^{17}$ This means that once organized crime considers teenagers as the "new social and human resource," they are forced to commit antisocial behavior because if caught they will not be prosecuted as adults would be and they will be released shortly after. This is particularly true for migrant boys, girls and teenagers (MBGT): Whether accompanied or alone, infants take the adventure to find their families or they run from poverty but they are both mentally and physically immature and most of the times they do not know the language or the local Laws. These factors turn them into victims and their rights are violate in a wide range from mistreatments, from sexual exploitation and forced labor, to being abused by authorities, deportation or imprisonment. ${ }^{18}$

Table 4 Population inside the centers for Teenagers, Admitted and Place of birth (higher number), 2016

\begin{tabular}{lllllll}
\hline State & \multicolumn{2}{l}{ Place of Birth } & & & Total \\
\hline & México & Estados Unidos & Guatemala & Honduras & El Salvador \\
\hline Total National & 7633 & 96 & 23 & 16 & 15 & 7785 \\
Baja California & 652 & 19 & 0 & 0 & 6 & 672 \\
Chiapas & 262 & 0 & 19 & 1 & 7 & 294 \\
Chihuahua & 614 & 20 & 1 & 1 & 0 & 636 \\
Distrito Federal & 1140 & 2 & 0 & 3 & 1 & 1146 \\
Jalisco & 583 & 3 & 0 & 1 & 0 & 586 \\
Nuevo León & 951 & 4 & 0 & 0 & 1 & 959 \\
Sonora & 634 & 8 & 0 & 1 & 0 & 642 \\
Tamaulipas & 593 & 29 & & & 5 \\
\hline
\end{tabular}

Source: own elaboration with Inegi data, 2016.

According to Moreno \& Avendaño, ${ }^{9}$ in this scenario, boys, girls, and teenagers (BGT) are the most susceptible to have their rights violated because they travel alone or they have unfitted companions. For this reason, they are exposed to high danger situations where their physical integrity gets compromised to human smugglers, drug traffickers and forced prostitution networks. ${ }^{9}$ from the total population of teenagers inside the Treatment Centers in 2016, the Mexican northern states represent 47 percent of the national total. Six States have near half of the population in the Treatment Centers: 3,712 of 7,785 teenagers. $^{3}$ This makes us wonder; what is happening in the northern border? Who are the inmates in the Treatment Centers? What are the socio-cultural characteristics of the teenagers that are there? Is the northern border a space that attracts teenagers to commit antisocial behaviors? What are the most vulnerable moments when the teenagers are pushed to take decisions that may jeopardize their physical integrity and their liberty? I propose the hypothesis that is focused on the re-conceptualization of these actors, which means a conceptual transition that a Transit Migrant Teenager (TMT) may experience to become a Circuit Migrant Teenager (CMT). This is mainly because in this particular moment of the migrant process they experience much vulnerability. The conceptualization of the actors turns out fundamental because they are essential to present how the different situations of vulnerability appear and surround some actors. Once the social actor is consider as a circuit migrant teenager, he is susceptible of being caught by delinquent organizations and forced to commit actions outside the law. Pastor Arnold Linares who runs the humanitarian center "Door to Missions" in Sand Pedro Sula, Honduras said "a mob boss once told us: Keep the boys busy otherwise we will", ${ }^{19}$ this is a very disturbing statement. The possibility of become a victim of organized crime in an unknown context is very high for a minor if we consider the fact that he has added several situations of vulnerability during his trip. This is said by the interviewed teenagers 
in the next Figure 3. The fact that a teenager has been caught twenty three times shows two things: first is "normalization", the teenager normalizes committing crimes and felonies; second authorities have certain perceptions on how they have to protect the integrity of children and underage people. In addition to these two situations there is the fact that crime organizations see invaluable experience in those minors that have been multiple detained because they have learnt routes, strategies, speeches etc. Such information is highly valued. The actor has gained training in the field, to certain point he is a professional and now he can be hired to better payments from the best buyer.

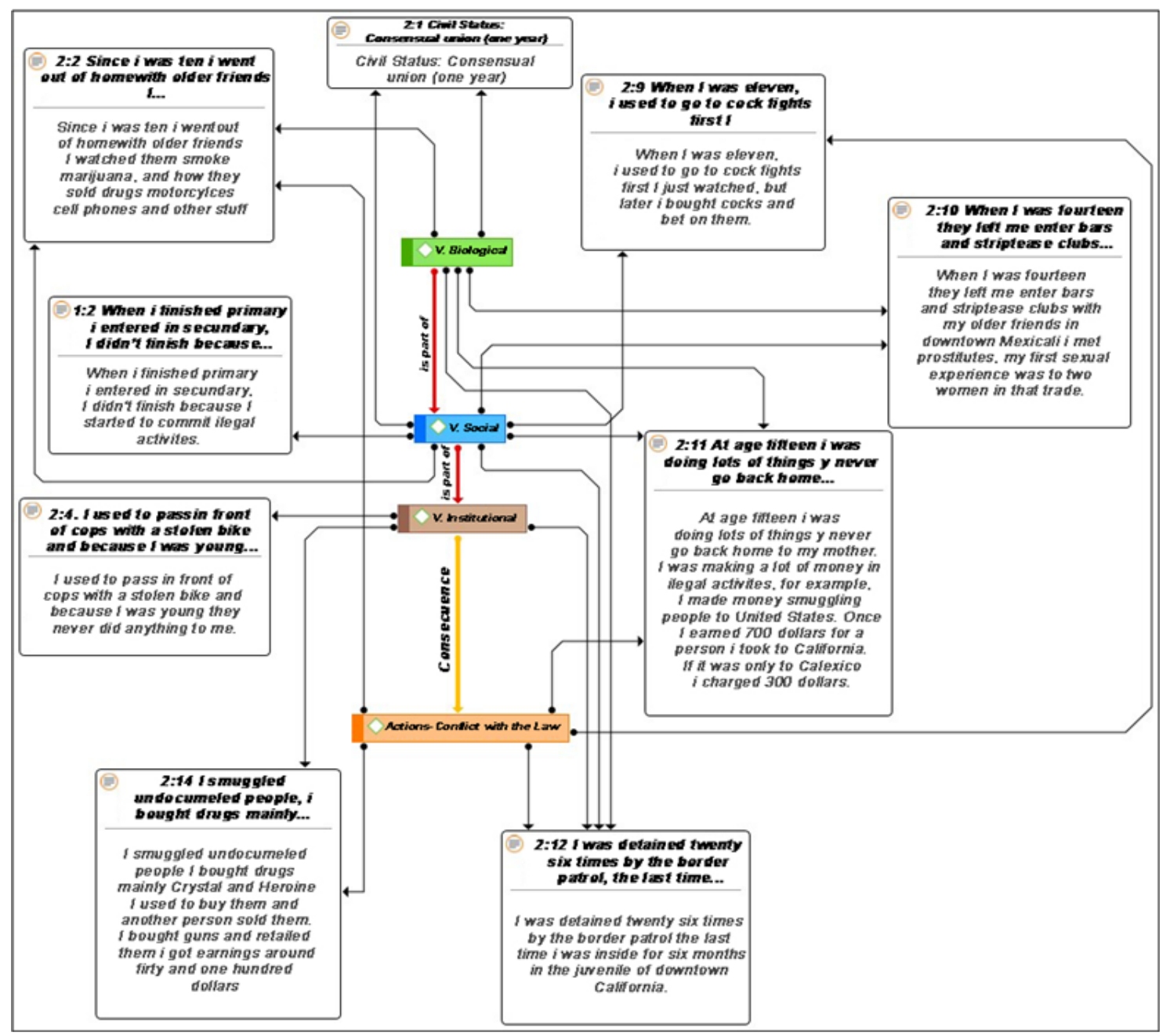

Source: own elaboration.

Figure 3 Accumulation of vulnerabilities.

\section{Conclusion}

This paper presents the concept of Migrant Teenager in Conflict with the Law as every person between 14 and 19 years old, who is imprisoned in a Treatment Center for Teenagers and has experienced a movement from his place of birth and residence in search for conditions that allow him to get better life alternatives.

This concept has its bases in three dimensions:

a) Biological: stage of life characterized by political, economic and cultural changes; sexual maturity; group behavior tendencies; and evolution from concrete to abstract thinking.

b) Social: space movement that is aiming the change from the place of birth or residence to a different place. The movement is an answer to a personal situation (to improve quality of life). c) Legal: International and national regulations protect the integrity of every boy, girl, and teenager; but; he/she is deprived of its liberty and awaits its due process.

One of the most relevant propositions in this paper is to bring attention to different vulnerability situations that migrant boys, girls, and teenagers face. A common characteristic in every regulation (whether international, national, state, or local) is to consider all human beings to be similar. This limits a fundamental part in the particular context where the MBGT (whichever it is) live. Different elements such as biologic, social and legal characteristics add to the fact of being in a geographic space like the Mexican northern frontier; in the MBGT that travel alone and are stuck in a strange space tend to an only aim: survival in a hostile context. The low or non-existent penalties in the Mexican and U.S. justice systems towards underage people have become an incentive for the organized crime groups to force 
boys, girls, and teenagers into decisions that can make them gain great quantities of money. These decisions turn into a life strategy because the main actors in this paper are going through different situations of vulnerability. It is stated that the condition in which Migrant Teenagers in Conflict with the Law are is one characterized by the addition of several different situations of vulnerability. These teenagers may take decisions based on their biologic, social, and legal conditions that could affect their everyday physical and psychological integrity. This implies that a teenager can commit an antisocial behavior that may put him in risk of losing his liberty if his participation is proven. It is very important to say that once a teenager has been through a repatriation process, being in a border like the one in northern Mexico, his survival strategies are reduced to gain an income by any means possible. If a teenager (alone or accompanied) is proven involved in a crime and is imprisoned, this would add another vulnerability element: to live his/ her imprisonment in an unknown place. There is not any evidence related to any kind of attention protocol for migrant imprisoned teenagers. The former Director of the Treatment Center for Teenagers is clear in this point; in the personal communication we had with him, he said there is not any attention protocol for Migrant Teenagers in Conflict with the Law thanks to the legal homogenization in every international, national, and local regulation as stated before. Based upon the information gathered, it is clear that Migrant Teenagers in Conflict with the Law are migrant actors with different situations of high vulnerability and these must be considered when the teenagers receive attention. I propose as an element of analysis, the visibility of the actors through the three dimensions exposed in this paper. If Migrant Teenagers are recognized in their three dimensions, Mexico as a country that signed the Convention on the Rights of the Child would walk towards the prevention of antisocial behaviors that endanger the minor's physical integrity and their liberty, thus it would represent a step in the right direction to achieve an integral attention for boys, girls, and teenagers. The Treatment Centers for Teenagers has as an objective the reinsertion to society of the teenagers in conflict with the Law, but there are several elements to say that at least that does not happen for the Migrant Teenagers in Conflict with the Law. Mexico as a signing country in different agreements and conventions on Child rights has an area of opportunity in the case of the Migrant Teenagers in Conflict with the Law. To bring to the front one of the main actors in the international migration process between Mexico and the United States would imply a transdisciplinary job focused to build integral propositions that consider the three spheres that the actors contain. At the same time, this would prevent recruitment by organized crime because contention strategies that take into consideration the addition of different vulnerability situations would be designed. This addition must be a priority.

\section{Acknowledgments}

None.

\section{Conflicts of interest}

The author declares that there are no conflicts of interest.

\section{References}

1. United Nations Children's Fund (Unicef). Convention on the Rights of the Child. Madrid: Unicef; 2006. 52 p.
2. Pineda Pérez, Susana, Aliño Santiago, et al. The concept of teenage hood. In: Manual of Clinic practices for integral care of youth health. La Habana, Cuba: MINSAP. 2009. 53 p.

3. National Institute of Statistics and Geography. National government Census, Public Security and State Penitentiary System 2016. México: Inegi; 2016.

4. Ramírez Romero, Silvia Jaqueline, García Hidalgo Jorge, et al. Beyond the frontier, migrant childhood: they are everybody's children. Exploratory research on migrant repatriated children's protection in the northern border. México: Possible Roads Research, Training and Development S.C; 2009. 371 p.

5. United Nations Children's Fund (Unicef). The state of the world's children 2011 Adolescence: An Age of Opportunity. NY: Unicef; 2011. 148 p.

6. International Organization for Migration (IOM). Glossary on migration. International Law on migration. Ginebra: OIM; 2006. 81 p.

7. Ruíz García Aida. Oaxacan Migration. An approach to reality. Oaxaca: State Coordination of Oaxacan migrant attention; 2002. 346 p.

8. Méndez Navarro, Jimena. Underage presence in international migration: an introductory research on the sociodemographic profile of the repatriated minors by Tijuana city 1999. Journal of Ethnic and Migration Studies. 2000;45(2):197-217.

9. Moreno Mena, José Asención, Avedaño Millán, et al. Cornered by reality: Circuit minors. Frontier Studies, New time. 2015;16(31):207-238.

10. Rivera García Óscar. Humanitarian Crisis: social networks in the migrant process. Germany: Spanish Academic Editorial; 2017. 122 p.

11. Corte Silva José. Internment measure. In: Conventional Justice system for teenagers, Azar, Enrique (Presidential). Conference held during 3rd International Congress on Justice for teenagers, México. México City. 2014.

12. United Nations Children's Fund (Unicef). United Nations Standard Minimum Rules for the Administration of Juvenile Justice (the Beijing Rules). NY: Unicef; 1985. 17 p.

13. Chamber of Deputies of the Congress of the Union [CDCU]. National law of the integral penal justice system for teenagers. 2016.

14. Jiménez Ornelas, René Alejandro. Youth Delinquency: modern society phenomenon. Population papers. 2005;11(43):215-261.

15. Guerrero, Ana Luisa. Los polleritos: Children migrant smugglers. Conacyt, Informative Agency. 2017.

16. Mosso Castro, Rosario, Torres Cruz, et al. Wave of sicaritos. Proceso Magazine, No. 1908-may, México. 2013. p. 13-17.

17. Ortiz Mayen, Arturo. They catch a child with drugs; he's afraid of his boss. The Universal. 2017. $355 \mathrm{p}$.

18. Higuera Aguilar, Luis Enrique. Polarized frontiers, shared realities: where are the rights of the child migrant population? In: Mena José, Valencia López, Cristian y Niño Contreras Lya, editors. Frontier Studies: New migration stages, coordinated by Moreno. Mexicali: Baja California State University; 2016. p. 163-179.

19. United Nations Office on Drugs and Crime (UNODC). Compendium of United Nations standards and norms in crime prevention and criminal justice. NY: ONU; 2007. 408 p. 